\title{
Effects of Hydroponic Fodder Feeding on Milk Yield and Composition of Dairy Cow: Review
}

\author{
Sefa Salo \\ Wachemo University, Department Of Animal Science
}

\begin{abstract}
The aim of this paper was to review the effects of hydroponic fodder feeding on milk yield and composition of the dairy cow. Hydroponic fodder is an effective solution for fodder scarcity and is very promising for sustainable livestock production in different regions of the world. Hydroponics fodder production involves growing of plants without soil for a short duration (5-10 day). In hydroponic fodder production system, it can be possible to grow 5$10 \mathrm{~kg}$ of green fodder from $1 \mathrm{~kg}$ seeds. The nutritional increase in crude protein, fibre, ether extract, vitamins and minerals were constantly observed in hydroponic fodder. However, there was a loss of 10-25\% dry matter content depending on grain type and duration. The hydroponics fodder feeding improves milk yield and composition of a dairy cow through increased intake and digestibility of nutrients. However, more information is needed to confirm the benefit of hydroponic fodder feeding as part of ration for dairy cow.
\end{abstract}

Keywords: hydroponic fodder, nutrient composition, dairy cow, milk yield, milk composition

DOI: $10.7176 /$ JNSR/9-8-01

Publication date: April $30^{\text {th }} 2019$

\section{Introduction}

Green fodder is the natural diet for livestock (Jemimah et al., 2018). For a sustainable dairy farming, quality green fodder should be fed regularly to the dairy animals (Naik et al. 2012a). However, due to many reasons, green fodder production has been facing a serious crisis and so the dairy cow productivity (Jemimahe et al., 2018). The major constraints in production of green fodder by dairy farmers are the unavailability of land for fodder cultivation due to small land holding size, more growth time and natural calamities. Further, the non-availability of quality fodders round the year aggravates the constraints of the sustainable dairy farming (Naik et al., 2013a). Due to these constraints, hydroponics technology becomes as an alternative way for growing fodder for farm animals (Sneath and Mclntosh, 2003, Naik et al, 2011a, Naik et al., 2012b, Naik et al., 2013b, Naik, 2014). The technology of green fodder production is especially important in the regions where forage production is limited (Abu Omar et al., 2012) due to natural calamities. The green fodder is produced from grains, having a high germination rate and grown for a short period of time in a special chamber that provides the appropriate growing conditions (Sneath and McIntosh, 2003). The adoption of this technique has enabled the production of fresh forage from oats, barley, wheat and other grains (Rodriguez-Muela et al., 2004). Over recent years, severe shortages in feed supplies for livestock have been experienced in many countries due to repeated droughts as well as shortages of water for irrigation (Abu Omar et al., 2012; Al-Karaki, 2011). Therefore, many projects to produce forages have been established during the last two decades to cover some green and dry forage needs in these countries (Al-Karaki, 2011).

Sprouting is a simple technique to germinate the seeds for the improvement of their nutritive value (Amal et al., 2007). It is reported that green fodder produced under hydroponic conditions has high metabolizable energy, crude protein and digestibility (El-Morsy et al., 2013). Nutritional value of sprouted grain improves due to the conversion of complex compounds into simpler and essential form and by minimizing the effect of anti-nutritional factors during germination (Chavan and Kadam, 1989). Sprouting of grains has resulted in not only increased protein quantity but also quality. This is further complemented by increased sugars, certain minerals and vitamin contents. It has also increased the plant enzyme contents (Shipard, 2005). These enzymes convert the complex compounds of protein into albumin and globulin thus, improves the protein quality (Shewry et al., 1995). Activation of amylase and lipase during germination also increases the sugar and essential fatty acid content of grains (MacLeod and White, 1962; Chavan and Kadam, 1989). Indeed, using sprouted barley and maize in growing goat revealed improvement in digestibility of nutrients, body weight gain and feed conversion efficiency. Similarly, the inclusion of hydroponic oats in feeding sheep seems to improve the milk production (Micera, 2009). Therefore, the objective of this paper was to review the effects of hydroponic fodder feeding on performance of dairy cow.

\section{Hydroponic Fodder Production}

The word hydroponics has been derived from two Greek words hydro means 'water' and ponic means 'working'. Thus, fodder produced by growing plants in water or nutrient rich solution but without using any soil is known as hydroponics fodder or sprouted grains or sprouted fodder (Dung et al., 2010a). Hydroponics is the state of technology that has revolutionized the green fodder production in the $21^{\text {st }}$ century. Hydroponics is a method of growing green fodder without soil in environmentally controlled houses or machines (Al-Karaki and Al-Hashimi, 
2012). Hydroponic fodder is an effective solution for fodder scarcity and is very promising for sustainable livestock production in different regions. It is essentially the germination of a seed and sprouted into a high quality, highly nutritious, disease-free animal food in a hygienic environment free of chemicals like insecticides, herbicides, fungicides and artificial growth promoters (Jensen and Malter, 1995; Al-Hashmi, 2008). This process takes place in a very versatile and intensive hydroponic growing unit where only supplying cereal grain with necessary water, nutrients and sunlight to produce a grass and root combination that is very lush and high in nutrients. This green fodder is extremely high in protein and metabolizable energy, which is highly digestible by most animals (ElMorsy et al., 2013). Hydroponics is a year-round growing system that produces a consistent quantity and quality of plant material or fodder, regardless of outside weather.

In hydroponics fodder production technology, water-soaked seeds are kept on trays and allowed to germinate (sprout) inside controlled environment for a short duration (Taparauskiene, 2015). Green fodder production takes 5 to 10 days (Cuddeford, 1989; Mooney, 2005; Merisco, 2009) with a $0.5 \mathrm{~m}^{3}$ usage of water for production of 1 tons of feed in the area of about $100 \mathrm{~m}^{2}$ (Taparauskiene, 2015). From $1 \mathrm{~kg}$ seeds, it can be possible to grow $5-10 \mathrm{~kg}$ of green fodder (Buston et al., 2002; Shtaya, 2004; Al-Karaki, 2011; Islam et al., 2016). In addition to this, recycling of water in hydroponic fodder production system allows solving problems related to water scarcity. At the end of the growing period, the fodder is fed to livestock as a supplement in the same way that hay and silage are currently used (Merisco, 2009).

\section{Nutritive Value of Hydroponic Fodder}

The chemical composition of hydroponic fodder grown from various grains was reported by different research in various conditions. There is a general consensus that there is no significant gain in fodder dry matter increase through sprouting grain and producing hydroponic fodder when compared to the starting dry matter of the grain used. Grain usually contains around $85-87 \%$ dry matter and hydroponic fodder usually contains $80-85 \%$ water (Weldegerima, 2015). Research results show a large diversity in dry matter gain or loss, ranging from $10 \%$ loss to $15 \%$ gain over 8-10 sprouting cycle (Starova, 2016). Abd Rahim et al. (2015) stated that the germination of barley resulted in about 18\% loss in DM. Similarly, Shtaya (2004) showed that the germination of wheat for 5 to 7 days resulted in a $17 \%$ loss of total DM while a $25 \%$ loss in DM of wheat after 12 days of sprouting. Loss of DM is probably due to the use of carbohydrates and energy by seeds for metabolic activities of the growing plant, without adequate replacement by photosynthesis of the young plant. This photosynthesis begins around the fifth day when the chloroplasts are activated (Al-Karaki and Al-Momani, 2011; Adjlane et al., 2016). In Dung et al. (2005) study, there was a $21.9 \%$ loss of DM over 7 day sprouting period. Seed soaking leads to the activation of enzymes, solubilisation and digestion of starch stored in the endosperm to simple sugars. This provides a substrate for the young developing plant for metabolic activities. These substrates are respired to produce energy, giving off carbon dioxide and water. This loss of carbon dioxide leads to a loss in dry matter (Emam, 2016).

Table 1. Summary of hydroponics barley chemical composition

\begin{tabular}{llllll}
\hline \multicolumn{7}{l}{ Variable } & DM & MM & OM & TNC & CF \\
\hline Dry seeds & $88.9 \pm 0.1$ & $4.02 \pm 0.4$ & $95.98 \pm 0.4$ & $11.3 \pm 2$ & $7.66 \pm 0.7$ \\
Soaked seeds & $62.0 \pm 0.1$ & $4.2 \pm 0.1$ & $95.8 \pm 0.1$ & $9.2 \pm 0.3$ & $16.7 \pm 0.9$ \\
4 days & $22.3 \pm 1.6$ & $2.6 \pm 0.2$ & $97.4 \pm 0.2$ & $11.1 \pm 0.1$ & $9.3 \pm 1.2$ \\
6 days & $17.8 \pm 2$ & $2.9 \pm 0.3$ & $97.1 \pm 0.3$ & $11.6 \pm 0.6$ & $10.9 \pm 0.4$ \\
8 days & $16.91 \pm 2$ & $35 \pm 0.1$ & $95 \pm 0.1$ & $15.6 \pm 0.1$ & $19.2 \pm 0.9$ \\
Leaves & $8.1 \pm 0.14$ & $5 \pm 0.0$ & $95 \pm 0.0$ & $27.1 \pm 0.7$ & $21.40 \pm 0.4$ \\
Roots & $8.1 \pm 0.6$ & $4.1 \pm 0.2$ & $95.9 \pm 0.2$ & $12.9 \pm 1.6$ & $24.3 \pm 0.5$ \\
\hline
\end{tabular}

DM: dry matter; MM: mineral matter; OM: organic matter; TNC: total nitrogen content. CF: crude fiber; fodder units. (Source: Adjlane et al., 2016)

However, the nutritional quality gains are constantly noted in hydroponic fodder. This is especially in crude and digestible protein, the gains of which range from $2-4 \%$. The same is valid in various extents for some vitamins and micro-nutrients. Protein, which is not used for growth, increases in sprouted grain. This increase in protein was due to a decrease in dry weight through respiration during germination (Sale, 2015). The absorption of nitrates facilitates the metabolism of nitrogenous compounds from carbohydrate reserves, thus increasing crude protein levels. Fiber content increased from 3.5\% in cereal barley grains to $6.5 \%$ and $8 \%$ in a 5 and 8 day green barley fodder, respectively (Abd Rahim et al., 2015). Chung et al. (1989) found that the fiber content was increased from $3.75 \%$ in barley grain to $6 \%$ in 5 -day sprouts. In Dung et al. (2005) study, there were an increase in crude protein and some mineral concentrations (except B, Mn and K) in sprouts in comparison to the grain. 
Table 2. Comparison of hydroponically produced wheat forage to wheat pasture

\begin{tabular}{lll}
\hline Nutrient & Hydroponics green fodder & Conventional green fodder \\
\hline DM & 22 & 21 \\
Crude protein $(\mathrm{g} / \mathrm{kg})$ & 288 & 200 \\
Crude fat $(\mathrm{g} / \mathrm{kg})$ & 93 & 40 \\
Crude fiber $(\mathrm{g} / \mathrm{kg})$ & 65 & 180 \\
Total digestible energy $(\mathrm{MJ} / \mathrm{Kg})$ & 187 & 187 \\
\hline Macro-elements $(\mathrm{g} / \mathrm{kg})$ & & \\
\hline Phosphorus & 9 & 3.6 \\
Potassium & 3500 & 31 \\
Calcium & 2.9 & 3.5 \\
Sodium & 3.2 & - \\
Chloride & 1900 & 6.7 \\
\hline Source: & &
\end{tabular}

Source: Ghaly et al., 2007

Thadchanamoorthy et al. (2012) studied hydroponic maize fodder as a source of feed for six New Zealand White rabbits ( 4 to 5 weeks old). At $10^{\text {th }}$ day after planting moisture, ash, CP, EE, CF, NDF and ADF\% in sprouted maize were higher $(73.93,3.09,16.54,6.42,8.21,29.27$ and $10.16 \%$ respectively) than the levels found in grain $(10.26,1.48,8.21,4.69,2.11,19.22$ and 5.5\% respectively). Lorenz (1980) stated that the sprouting of grain caused increased enzyme activity, a loss of total DM, an increase in total protein, a change in amino acid composition, a decrease in starch, increases in sugars, a slight increase in crude fat and crude fiber, and slightly higher amounts of certain vitamins and minerals. Most of the increases in nutrients are not true increases; they simply reflect the loss of DM, mainly in the form of carbohydrates, due to respiration during sprouting. As total carbohydrates decreases, the percentages of other nutrients are increases (Dung et al., 2005; Helal, 2015).

Table 3. Nutrient changes in barley sprouted over a 13-day period

\begin{tabular}{llllll}
\hline & \multicolumn{5}{c}{ Harvest days } \\
\cline { 2 - 6 } Parameters & Original seed & 4 & 7 & 10 & 13 \\
\hline DM & 90.40 & $202.32^{\mathrm{a}}$ & $136.14^{\mathrm{b}}$ & $103.04^{\mathrm{c}}$ & $102.28^{\mathrm{c}}$ \\
CP & 12.7 & 177.19 & 171.05 & 182.50 & 175.93 \\
NDF & 13 & 470.10 & 510.17 & 525.35 & 540.53 \\
ADF & 6.0 & $166.53^{\mathrm{c}}$ & $214.61^{\mathrm{b}}$ & $236.34^{\mathrm{ab}}$ & $261.47^{\mathrm{a}}$ \\
ADL & - & 30.73 & 39.24 & 59.49 & 51.48 \\
Ash & 2.2 & $43.89^{\mathrm{c}}$ & $49.78^{\mathrm{b}}$ & $53.90^{\mathrm{ab}}$ & $57.57^{\mathrm{a}}$ \\
\hline
\end{tabular}

Source: AKbă̆ et al., 2014

In Al-saadi (2016) study, the crude protein, ash, ether extract, non-protein nitrogen, true protein and neutral detergent fiber were significantly higher in green fodder comparative to grain. According to Resh (2001), sprouting of grains affected the enzyme activity, increased total protein and changes in amino acid profile, increased sugars, crude fiber, certain vitamins and minerals, but decreased starch and loss of total dry matter. The enzymes also cause the inter-conversions of these simple components leading to an increase in quality of amino acids as well as the increase in concentrations of vitamins (Plaza et al., 2003).

Table 4. Proximate composition of sprouted sorghum and grain at 7 days

\begin{tabular}{lll}
\hline Constituent (DM basis) & Sorghum Grains & Sorghum sprouts \\
\hline Dry matter & $95.08^{\mathrm{a}}$ & $24.61^{\mathrm{b}}$ \\
Crude protein \% & $4.1^{\mathrm{b}}$ & $4.92^{\mathrm{a}}$ \\
Ether extract & $1.45^{\mathrm{b}}$ & $2.15^{\mathrm{a}}$ \\
Ash \% & $1.08^{\mathrm{b}}$ & $1.12^{\mathrm{a}}$ \\
Crude Fiber\% & $1.06^{\mathrm{b}}$ & $2.16^{\mathrm{a}}$ \\
\hline
\end{tabular}

Source: Sale, 2015

\section{Effect on Intake}

Determination of dry matter intake is very important in feed evaluation, not only to prevent the deficiency or excess intake of nutrients but also can assist the use of nutrient efficiently (NRC, 2001). There are some arguments about the use of the sprouting grains for the convenience of green forage production in hydroponics system to be as part of feed in livestock feeding systems (Shtaya, 2004; Prasad, et al., 1998; Tudor et al., 2003). Sole feeding of green fodder did not support the expected production traits in the animals whereas feeding in conjunction with dry fodder improved its utilization (Prasad et al., 1998). Abd Rahim et al. (2015) noted that the dry matter intake of green fodder by feedlot cattle and dairy cattle were low due to its high moisture content. The total consumption of both as fed and dry matter was higher in dairy cows receiving 7\% maize hydroponic fodder as supplementation compared with control treatment (Nugroho et al., 2015). This could be caused by a good palatability of maize 
hydroponic fodder, so it could stimulate the increased consumption of other types of feed (Singh; Chaudry, 2007). However, there was a report which indicates a decrease in the DM intake of the animals when hydroponics fodder is fed (Heins and Paulson, 2016). Similarly, Naik et al. (2014) were reported lower dry mater intake on supplementation of hydroponic fodder for dairy cow. Lower DM intake associated with the feeding of hydroponics green fodder may be due to the high water content of the hydroponics green fodder that might have made it bulky leading to limited DM intake by the animals (Fazaeli et al. 2011).

Table 5. Least squares means for economics by fodder group for organic dairy cows

\begin{tabular}{lll}
\hline Measurement & No Fodder & Fodder \\
\hline Dry matter intake $(\mathrm{kg} / \mathrm{cow})$ & $17.5^{\mathrm{a}}$ & $14.5^{\mathrm{b}}$ \\
DMI/milk & 1.35 & 1.27 \\
\hline
\end{tabular}

(Source: Heins and Paulson, 2016)

\section{Effect on Digestibility}

Nutrient digestibility increased by using sprouted grains in the ruminant diet. Fayed (2011) determined that the addition of sprouted barley with rice straw and Tamarix Mannifera increased DM, OM, CP, EE, CF, NDF and ADF digestibility. This may be due to the presence of bioactive catalysts which increases digestion and absorption of nutrients and the release of energy. Similarly, Ibrahim et al. (2001) reported that addition of sprouted grains increases nutrient digestibility. Sharif et al. (2013) observed increased digestibility by using sprouted grain in the diet of broilers and large animals. This was achieved possibly by changes in rate and extent of digestion and absorption. During germination, enzymes are produced which reduces the viscosity of the digesta and improves the digestion and absorption of nutrients (Annison, 1993). This is also due to the presence of grass juice factor (Finney, 1982; Elvehjen et al., 1934) which may be a good source of nutrients for rumen micro-organisms. Table 6. Dry matter and nutrient digestibility on dairy cows

\begin{tabular}{lccc}
\hline & & Treatment \\
\hline Digestibility (\%) & NMHF & MHF \\
Dry matter & & $76.0 \pm 8.99$ & $77.0 \pm 4.24$ \\
Organic matter & $78.0 \pm 8.49$ & $78.5 \pm 3.99$ \\
Crude protein & $83.0 \pm 6.27$ & $82.6 \pm 3.35$ \\
Ether extract & $91.5 \pm 3.86$ & $90.9 \pm 1.68$ \\
Nitrogen free extract & $76.0 \pm 9.01$ & $76.9 \pm 4.14$ \\
Total digestible nutrient & $71.8 \pm 7.52$ & $72.7 \pm 3.54$ \\
\hline
\end{tabular}

NMHF=no maize hydroponic fodder, $M H F=$ maize hydroponic fodder (Source: Nugroho et al., 2015)

Moghaddam et al. (2009) conducted an experiment to determine the effect of sprouted grains on nutrient digestibility. They replaced barley with sprouted barley at the level of $0,33,66$ and 100\%. They concluded that nutrient digestibility was increased by increasing the level of sprouted barley. They reported that $100 \%$ replacement resulted in better nutrient digestibility as compared to other levels. Similarly, Helal (2015) reported that digestibility coefficients of all nutrients were significantly higher in sprouted barley supplemented sheep. In general, feeding of hydroponics fodder increased the digestibility of the nutrients of the ration which could be attributed to the tenderness of the fodder (Reddy et al., 1988). In the Naik et al. (2014) study, there was increased $(\mathrm{P}<0.05)$ in the digestibility of $\mathrm{CP}$ and $\mathrm{CF}$ of the cows due to a feeding of hydroponics maize fodder. However, the increase $(\mathrm{P}>0.05)$ in the digestibility of DM, OM, EE and NFE was non-significant. These result revealed that feeding hydroponic fodder improves the digestibility of most nutrients.

\section{Effects on Milk Yield and composition}

Hydroponic fodder can help to improve the quality and quantity of milk production. Research results indicated that milk yield was improved. There were 3.9\% increase in the milk yield due to feeding of hydroponics barley fodder (Heins and Paulson, 2016) and 13.7\% increase in the milk yield due to feeding of hydroponics maize fodder (Naik et al., 2014), which may be due to the higher DCP and TDN content of the ration (Moghaddam et al., 2009; Naik et al., 2014, Helal 2015). Likewise, Grigorev et al. (1986) showed that replacing 50\% of the maize silage with $18 \mathrm{~kg}$ of hydroponic barley grass increased cows' milk yields by $8.7 \%$, while milk fat was depressed. This improvement may be due to increase in nutrient quality of hydroponic fodder through sprouting. Early research on hydroponic sprout reported the presence of a grass juice factor that improved livestock performance (Finney, 1982; Elvehjen et al., 1934). More recent research has also indicated that hydroponic sprouts are a rich source of nutrient and they contain the grass juice factors that improve the performance of livestock (Nutrigrass, 2007). Adjlane et al. (2016) study on dairy cows supplemented with hydroponic barley (10kg) indicated that milk yield was increased significantly (16.14 vs. 13.49 litre/day). Abd Rahim et al. (2015) were also observed a slight improvement in milk protein, milk fat and total solids in dairy goat but were not significant in sheep supplemented with barley green fodder. 
Table 7. Summary table of the main results obtained in 2 lots of cows

\begin{tabular}{llll}
\hline & Lots & Control group & Experimental group \\
\hline Milk production (1) & Before test & $14.65 \pm 0.70$ & $15.38 \pm 0.19$ \\
& During test & $13.49 \pm 1.71$ & $16.14 \pm 1.48$ \\
TDE (\%) & $11.32 \pm 0.52$ & $11.23 \pm 0.82$ \\
SNF (\%) & $6.98 \pm 0.16$ & $6.90 \pm 0.15$ \\
& Water (\%) & $88.68 \pm 0.52$ & $86.86 \pm 4.29$ \\
& Fat content (\%) & $4.31 \pm 0.42$ & $4 \pm 0.30$ \\
& Protein content (\%) & $2.66 \pm 0.05$ & $2.62 \pm 0.07$ \\
\hline
\end{tabular}

$T D E=$ total digestible energy; $S N F=$ solid not fat (Source: Adjlane et al., 2016)

A test completed on milk production with a diet of fodder versus one of the normal feeds such as grain, hay or silage showed a vast improvement in milk production and butterfat content. A group of 60 cows on a fodder diet increased their milk production by $10.07 \%$. In addition, the fodder fed group also produced a butterfat content of $14.26 \%$ higher as compared to those fed on a regular diet (Ryan, 2003). In another study from Canadian, there was an increase in $3.6 \mathrm{~kg}$ per day milk production per cow over the lactation period. Furthermore, from South Africa, milking cows dropped 3.6 litres of milk per milking after leaving off the green fodder, which was fed at the rate of $6.8 \mathrm{~kg}$ per day (Mooney, 2002). Naik et al. (2013) result also revealed that milk yield was increased by 0.5-2.5 litres/animal/day due to the feeding of hydroponic fodder to dairy animals. In Šidagis et al. (2014) study, they were concluded that malt sprouts were increased the whole milk yield and milk fat content, but had no significant influence on milk protein content. Naik et al. (2014) were reported $13.7 \%$ increase in the milk yield due to hydroponic maize feeding. These improvements might be due to a stimulated appetite of the cow as a result of the daily feeding of fresh green fodder (Ryan, 2003).

Table 8. Least squares means for production, SCS, MUN, body weight, and body condition score by fodder group for organic dairy cows

\begin{tabular}{lll}
\hline Measurement & No Fodder & Fodder \\
\hline Milk $(\mathrm{kg} / \mathrm{d})$ & 13.3 & 12.3 \\
Fat $(\mathrm{kg} / \mathrm{d})$ & 0.48 & 0.44 \\
Fat $(\%)$ & 3.75 & 3.68 \\
Protein $(\mathrm{kg} / \mathrm{d})$ & $0.39^{\mathrm{a}}$ & $0.35^{\mathrm{b}}$ \\
Protein $(\%)$ & 2.99 & 3.04 \\
Milk urea nitrogen $(\mathrm{mg} / \mathrm{dl})$ & $13.45^{\mathrm{a}}$ & $16.45^{\mathrm{b}}$ \\
Body weight $(\mathrm{kg})$ & 505.2 & 502.7 \\
Body condition score & 3.17 & 3.17 \\
\hline
\end{tabular}

(Source: Heins and Paulson, 2016)

However, Williams (1956) observed no change in milk production or fat percentage. In another study, Tinley and Bryant (1938) found that the difference in milk yield between the sprout-fed and control groups was not significant. Likewise, Chinnam (2015) in lactating buffalo reported no significant effect on milk production upon feeding hydroponic maize fodder. The conclusion of 8 tests by Bartlett et al. (1938) showed that feeding sprouted maize had no advantage in either milk yield or quality. Marisco et al. (2009) were also found no change in goat milk yield between those fed on hydroponic sprouts and those fed on traditional diets. Sheep milk yield, milk protein, milk fat and total solids were also not affected by feeding hydroponic barley.

\section{Conclusion}

Dairy cattle require green fodder for high milk yield. However, it cannot available throughout the year and in some area, it is difficult to have access for green fodder. Thus, hydroponic fodder production has become an alternative way to fulfill this green fodder requirement of the dairy cow. The adoption of this technique has enabled the production of fresh forage from grains without soil. Hydroponic fodder has high nutritive value due to the conversion of complex compounds into simpler and essential form, and activation of enzymes during germination. Thus, it contains high protein, vitamins and minerals which are essential for dairy cows. There were improvements in digestibility and intake of nutrients results in increased milk yields and quality like milk fat of dairy cow on the feeding of hydroponic fodder. In general, research data on dairy cows is limited to determine definitively whether or not feeding the fodder changes production enough to warrant the additional cost. Therefore, this area requires further information to draw a concrete conclusion about feeding hydroponic fodder.

\section{References}

Abd Rahim M.A. Saidi, Jamal Abo Omar, 2015. The biological and economic feasibility of feeding barley green fodder to lactating awassi ewes. Open Journal of Animal Sciences (5) 99-105.

Abu Omar, J., Daya, R. and Salama, A., 2012. Effects of different types of olive cake on the performance and carcass quality of Awassi lambs. Animal Feed Science and Technology, 171, 167-172. 
Adjlanea S.K., A. Ahmed Serirb M. Bafdelc and R.Benhacine, 2016. Techno-Economic Approach to Hydroponic Forage Crops: Use for Feeding Dairy Cattle Herd. J. Appl. Environ. Biol. Sci., 6(3)83-87.

Akbağ H.I., O.S. Turkmen, H. Baytekin, İ.Y. Yurtman, 2014. Effects of harvesting time on nutritional value of hydroponic barley production. Turkish Journal of Agricultural and Natural Sciences, Special Issue: 2.

Al-Hashmi, M.M., 2008. Hydroponic green fodder production in the Arabian Gulf Region. MSc. Thesis, Faculty of Graduate Studies, Arabian Gulf University, Bahrain.

Al-Karaki GN and Al-Hashimi M, 2012. Green fodder production and water use efficiency of some forage crops under hydroponic condition. Intern. Schol. Res. Network

Al-Karaki, G. N., Al-Momani, N. 2011. Evaluation of some barley cultivars for green fodder production and water use efficiency under hydroponic conditions. Jordan J. Agricultural Science 7 (3):448-456.

Al-Karaki, G.N., 2011. Utilization of Treated Wastewater for Green Forage Production in a Hydroponic System. Emirates Journal of Food and Agriculture, 23, 80-94.

AL-Saadi, M.J., 2016. Productive effects and economical feasibility of substitution barley by 10 and $30 \%$ of sprouted barley in diet of Awassi male lambs. Asian J. Anim. Vet. Adv., 11: 563-569.Bartlett S, Cotton A G, Henry K M, and Kon S K 1938. J. Dairy Res. 9: 273.

Amal B.K.; Aurang, Z.; Nizakat, B.; Shahid, A.K. and Mohammad, S.K. (2007). Influence of germination techniques on phytic acid and polyphenols content of chickpea (Cicer arietinum L.) sprouts. Food Chem. 104: 1074-1079

Annison, G. 1993. The role of wheat non-starch polysaccharides in broiler nutrition. Aust. J. Agric. Sci. 44:405422.

Bartlett, J.M., 1917. The chemical composition of green sprouted oats. Maine Agricultural Experimental Station.

Buston, C.D.E., Gonzalez, E.L. Aguilera B.A. and Esptnoz, G.J.A., 2002. Forrajehidropónicounaalternativa parala suplementacióncaprinaen el semidesier to Queretano pp: 383. XXXVIII Reunión Nacional de Investigación Pecuaria.

Chavan, J. and Kadam, S.S., 1989. "Nutritional improvement of cereals by sprouting." Critical Reviews in Food Science and Nutrition 28(5): 401-437.

Chinnam, H.K., 2015. Effect of feeding rations supplemented with hydroponic maize fodder on nutrient utilization and milk production in lactating Graded Murrah Buffaloes. AN MSc thesis submitted to the Sri Venkateswara Veterinary University. pp. 144.

Chung, T.Y., Nwokolo, E.N. and Sim, J.S. (1989) Compositional and Digestibility Changes in Sprouted Barley and Canola Seeds. Plant Foods for Human Nutrition, 39, 267-278.

Cuddeford D, 1989. Hydroponic grass. In Practice 11(5): 211-214.

Dung, D.D., Godwin I.R. and Nolan J.V., 2005. Nutrient content and in sacco digestibility of Grimmett barley grain and sprouts. Recent Advances in Animal Nutrition in Australia, Volume 15.

Dung, D.D., Godwin, I.R. and Nolan, J.V., 2010a. "Nutrient content and in sacco degradation of hydroponic barley sprouts grown using nutrient solution or tap water", J. Anim. Vet. Adv., Vol. 9, No. 18, pp. 2432-2436.

El-Morsy A.T., M. Abul-Soud and M.S.A. Emam, 2013. Localized hydroponic green forage technology as a climate change adaptation under Egyptian conditions. Research Journal of Agriculture and Biological Sciences, 9(6): 341-350

Elvehjem, C.A., Hart, E. Jackson H.C. and Weckel H.G, 1934. The nutritional values of Milk raw vs. Pasteurized and summer vs. winter .Dairy Science, 17:763-770.

Emam M.S.A., 2016. The sprout production and water use efficiency of some barley cultivars under intensive hydroponic system. Middle East Journal of Agriculture, 05 (02):161-170

Fayed, M.A., 2011. comparative study and feed evaluation of sprouted barley grains on rice straw versus Tamarix Mannifera on performance of growing Barki Lambs in Sinai. Journal of. Animal. Science. Pp: 7.

Finney, P.L., 1982. Effect of germination on cereal and legume nutrient changes and food or feed value: A comprehensive review, Phytochem. 17:229-305.

Grigor'ev, N.G., Fitsev, A.I. and Lesnitskaya, T.I., 1986. Nutritive Value of Hydroponic Feed and Its Use for Feeding High-Yielding Cows. Sel'skokhozyaistvennaya Biologiya, 7, 47-50.

Heins B., 2016. Evaluation of fodder systems for organic dairy cattle to improve livestock efficiency.

Helal H.G., 2015. Sprouted barley grains on olive cake and barley straw mixture as goat diets in Sinai. Advances in Environmental Biology, 9(22): 91-102

Ibrahim, A.F., M.H. Hoda and I.M. El-Sayed, 2001. Effect of using sprouted barley by recycle process of agriculture residues on feeding value, rumen activity and some blood constituents of crossbred sheep. Egypt. J. Nutr. Feeds, 4: 265-273.

Islam, R., Nabilah Jalal, Md. Ali Akbar, 2016. Effect of seed rate and water level on production and chemical analysis of hydroponic fodder. European Academic Research, 4 (8): 6724-6753.

Jemimahe, R., Gnanaraj, P.T., Muthuramalingam, T., Devi, T.and Vennila, C., 2018. Nutritive value of hydroponic yellow maize fodder and conventional green fodders-a comparison. Int. J. Agric.Sc \& Vet.Med., 
98-1001

Jensen, H. and A. Malter, 1995. Protected agriculture a global review. World Bank technical paper number 253. $156 \mathrm{p}$.

Kide, W., Desai B., Dhekale, J., 2015. Feeding effects of maize and barley hydroponic fodder on dry matter intake, nutrient digestibility and body weight gain of Konkan Kanyal goats. Life Sciences International Research Journal, 2(2).

Lorenz K., 1980. Cereal sprouts: composition, nutritive value, food applications. Crit. Rev. Food Sci. Nutr. 13(4): 353-385.

MacLeod, A.M., and White, H.B. (1962). "Lipid metabolism in germinated barley: barley lipase." J. Inst. Brew. London 38: 487.

Marisco, G. Miscera, E. Dimatteo, S., Minuti, F. Vicenti, A. and Zarrilli, A., 2009. Evaluation of animal welfare and milk production of goat fed on diet containing hydroponically germinating seeds. Italian Journal of Animal Science, 8(2),pp: 625-627.

Micera, E., M. Ragni., F. Minuti., G. Rubino., G. Marsico., A. Zarrilli, 2009. Improvement of sheep welfare and milk production fed on diet containing hydroponically germinating seeds. Italian Journal of Animal Sciences, $8(2): 634-636$.

Moghaddam, A.S., M. Mehdipour and B. Dastar. 2009. The determining of digestible energy and digestibility coefficients of protein, calcium and phosphorus of malt (Germinated Barley) in broilers. Inter. J. Poult. Sci. 8: 788-791.

Mohsen, M.K.1; E.M. Abdel-Raouf1; H.M.A. Gaafar2 and A.M. Yousif, 2015). Nutritional Evaluation Of Sprouted Barley Grains On Agricultural By-Products On Performance Of Growing New Zealand White Rabbits. Nature and Science, 13(10).

Mooney J., 2005. Growing Cattle Feed Hydroponically. 2002 scholarship report, Meat and Livestock Australia. $30 \mathrm{p}$

Naik P K, Dhuri R B, Swain B K and Singh N P. 2012b. Nutrient changes with the growth of hydroponics fodder maize. Indian Journal of Animal Nutrition 29: 161-63.

Naik P.K., R.B. Dhuri and N.P. Singh, 2011. Technology for production and feeding of hydroponics green fodder. Extension folder No. 45/2011.

Naik PK and Singh NP, 2013. Hydroponics fodder production: an alternative technology for sustainable livestock production against impeding climate change. Model Training Course on Management Strategies for Sustainable Livestock Production against Impending Climate Change. Southern Regional Station, National Dairy Research Institute, Adugodi, Bengaluru, India Pp. 70-75.

Naik, P.K, R.B. Dhuri, M Karunakaran, B.K. Swain and N.P. Singh, 2014. Effect of feeding hydroponics maize fodder on digestibility of nutrients and milk production in lactating cows. Indian Journal of Animal Sciences 84 (8): 880-883.

NRC, 2001. Nutrient Requirements of Dairy Cattle. 7th Revised Edition, National Research Council, National Academy Press, Washington DC.

Nugrohoa, H.D., I.G. Permanab and Despal, 2015. Utilization of bioslurry on maize hydroponic fodder as a corn silage supplement on nutrient digestibility and milk production of dairy cows. Media Peternakan 38(1):7076

Nutrigrass, 2007. The jointing stage: When nutrients reach their peak.

Pandey HN and Pathak NN, 1991. Nutritional evaluation of artificially grown barley fodder in lactating crossbred cows. Indian Journal of Animal Nutrition 8(1): 77-78.

Pandey, H.N. and Pathak, N.N. 1991. Nutritional evaluation of artificially grown barley fodder in lactating crossbred cows. Indian J. Anim. Nutr. 8 (1): 77-78.

Plaza, L., de Ancos, B. and Cano, M.P. 2003. Nutritional and health related compounds in sprouts and seeds of soybean (Glycine max), wheat (Triticum aestivum L.), and alfalfa (Medicago sativa) treated by a new drying method. Europ. Food Res. Technol. 216: 138-144.

Prasad, R., Seghal, J.P., Patnayak, B.C. and Beniwal, R.K., 1998. Utilization of artificially grown barley fodder by sheep. Indian Journal of Small Ruminants, 4, 63-68.

Reddy, G.V.N, Reddy M R and Reddy K.K., 1988. Nutrient utilization by milch cattle fed on rations containing artificially grown fodder. Indian Journal of Animal Nutrition 5 (1): 19-22.

Resh, H.M., 2001. Hydroponic food production, $6^{\text {th }}$ ed., 567 pp., Woodbridge Press, Santa Barbara, CA.

Rodriguez-Muela, C., Rodriguez, H.E., Ruiz, O., Flores, A., Grado, J.A. and Arzola, C., 2004. Use of green fodder produced in hydroponic system as supplement for lactating cows during the dry season. Proceedings of the American Society of Animal Science, 56, 271-274.

Ryan, Peter. Taree, NSW, Australia.

Sale S., 2015. Nutritive value of white kaura sorghum (SORGHUM BICOLOR L.Moench) grains and sprouts and their utilization by goats. An MSc. Thesis presented to Ahmadu Bello University, Zaria. Pp 
Sharif M, Hussain A and Subhani M 2013. Use of sprouted grain in the diets of poultry and ruminants. Indian Journal of Research 2 (10): 4-7.

Shewry, P. R., Napier, J.A., Tatham, A. S. 1995. Seed storage proteins: structures and biosynthesis. The Plant Cell 7, 945-956.

Shipard, I., 2005. How can I grow and use sprouts as living food. Steward publishing.

Shtaya, I., 2004. Performance of Awassi Ewes Fed Barley Green Fodder. Master Thesis, An-Najah National University,

Šidagis D., Virginijus Uchockis, Saulius Bliznikas, 2014. Effect of malt sprouts on nutrient fermentation in the rumen of cows and their productivity. veterinarija ir zootechnika (Vet Med Zoot). T. 65 (87).

Singh, B. and J. L. Chaudary. 2007. Effect of different levels of maize fodder on the performance of crossbred heifers. Indian Journal of Animal Nutrition. 24: 256-257.

Sneath, R. and McIntosh, F., 2003. Review of Hydroponic Fodder Production for Beef Cattle. Department of Primary Industries: Queensland Australia 84. McKeehen, p. 54.

Starova J., 2016. Hydroponic Fodder Production.

Taparauskiene, L., 2015. Case Example: Hydroponic green fodder production technology. EIP-AGRI Focus Group Water \& agriculture: adaptive strategies at farm level.

Thadchanamoorthy S, Jayawardena VP and Pramalal, 2012. Evaluation of hydroponically grown maize as a feed source for rabbits. Proceedings of 22nd Annual Students Research Session, Department of Animal Science.

Tinley N L and Bryant D M, 1938. A trial of the feeding value of dried grass and sprouted Maine for dairy cows. J.S.E. Agric. Coll. 42: 135.

Tudor, G., Darcy, T., Smith, P. and Shallcross, F., 2003. The intake and live weight change of drought master steers fed hydroponically grown, young sprouted barley fodder (Autograss). Department of Agriculture Western Australia.

Weldegerima Kide, 2015. Nutritional benefit and economic value of feeding hydroponically grown maize and barley fodder for Konkan Kanyal goats. IOSR Journal of Agriculture and Veterinary Science, 8(7):24-30

Williams JB, 1956. Sprouted oats in dairy cow rations. Department of Dairy Husbandry, Institute of Agriculture, University of Minnesota. 